\title{
Lunar talk
}

\section{How TV looks at the moon}

\author{
Louis Appleby
}

It can't be easy being the answer to the world's most obvious quiz question but Buzz Aldrin, the second man on the moon, seems to take it in his stride. Or at least he does now - there was a time when drinking and disappointment made it hard to tell what he thought. According to One Small Step, a superb mini-series of documentaries put out by BBC2 in July to commemorate Apollo 11's historic landing 25 years ago, returning from the moon left him let down and lacking direction. But that was the aftermath of the mission as a whole, Aldrin insisted, and nothing to do with having to follow Nell Armstrong out of the lunar module.

The point of this part of One Small Step was to recount how the Apollo astronauts who walked on the moon had reacted to the experience. Most were in their 30s when they took part in this

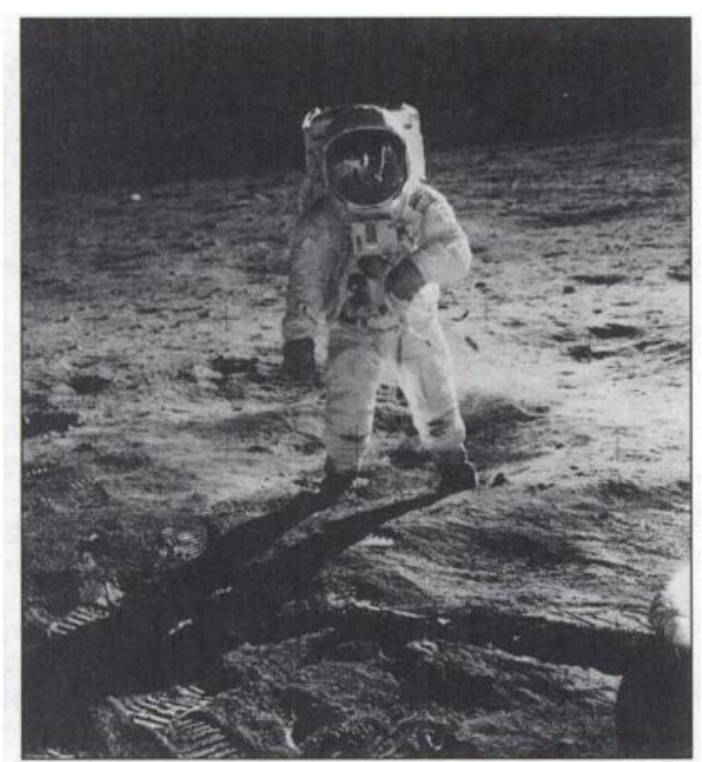

Apollo 11 astronaut Edwin E. Aldrin walks on the surface of the moon in this photograph taken by fellow astronaut Neil A. Armstrong. In Aldrin's face mask are reflections of Armstrong, the lunar module, television camera and the US flag. Copyright The Associated Press Ltd. most exhilarating of adventures, one small step this side of science fiction. Halfway through their lives, they had done something so remarkable that nothing else they could ever do would compare. It was unforgettable and unrepeatable and most of those appearing in the programme had spent their subsequent years trying to forget or in some way repeat it.

Alan Bean, for instance, the co-pilot of Apollo 12 and fourth man on the moon, had become an artist, painting only lunar landscapes. The materials he used - some sort of grey dirt intended to resemble moon mud, and an old astronaut's boot - revealed him as a man obsessed, if happlly so. This is more than could be said for Ed Mitchell (sixth) who couldn't bear to hear the moon mentioned. At least he had enough humour to allow the cameras to show him fiddling with the car radio, trying to find a station that was not playing a song with 'moon' in the lyrics.

The post-lunar let-down almost destroyed Charlie Duke (tenth). On returning to Earth, Duke was unable to talk about anything of importance, except himself. His marriage fell apart and his wife considered suicide. But evangelical religion had been able to fill the gap left by being a moonwalker and had saved them both. Now, said Duke, I'm on a walk with Jesus.

Only one astronaut, Pete Conrad (third) claimed to be unaffected. He thought about the moon, of course, but to him going there had been nothing more than a job. Conrad looked pretty contented too, and even if it was all denial, that seemed the best bet under the circumstances.

It was not only the Apollo crews who had to adapt to the end of lunar missions in the early '70s. So too did the 93,000 people who registered with PanAm to be on one of the first passenger flights to the moon whenever they should take place. Another programme in the One Small Step series interviewed a few of the ticket-holders, asking them why they had made their bookings. I wanted to see the Earth rise, said one. I was 17 and living at home, said another - it seemed like a good place to go.

What it all showed, without a psychiatric 'expert' in sight, was the importance of dreams, 
of planning future excitement, of seeing an escape from the restrictions of the present. At a time when the US was bogged down in Vietnam, getting to the moon meant a thrilling, innocent life ahead.

All but one of the interviewees would still jump at the chance of going there: many had kept their tickets safe like childhood ideals. Outside I'm in real estate, admitted a smartly dressed woman. inside I'm Buck Rogers. Some confessed to childlike visions of what it would be like. Like Disneyworld, said one ticket-holder. Another planned to leave a permanent footprint in the dust. What would you take with you, they were each asked. Potato chips, came back a typical reply.

Most knew they would never make it now that moon landings were out of fashion and PanAm had gone bust. But some still looked wistfully at the moon at night, while a resident of New York thought it was hard enough just getting across town. A lawyer in a bow-tie described how as a single college student he had applied for two tickets - one for the wife he expected to have acquired. Now, married with kids, he still wanted to go so that he could have a couple of days to himself. As a symbol of wish fulfilment, the moon had clearly captivated him, if not our whole culture. And the only person you couldn't understand was the man who no longer wanted to go.

Louis Appleby, Senior Lecturer, University of Manchester; Withington Hospital, West Didsbury, Manchester M20 8LR

\section{Broken Glass}

\section{Roisin Kemp reviews a new play by Arthur Miller.}

Is it possible for a Jewish woman in 1938 New York to develop hysterical paralysis of her legs in response to events in Nazi Germany? And how much are her symptoms a reaction to longstanding difficulties in her marriage to a man who is impotent, autocratic, subject to sporadic violent rages, and uncomfortable with his Jewish identity? Is it appropriate for an honest play which explores issues of prejudice, oppression, tryanny, and genocide to be simultaneously humorous and entertaining? What if at the end one feels almost as moved by the miserable (and dead) husband as the heroine, who finds the power to walk again only when her husband expires? These are the difficult questions posed by Arthur Miller in Broken Glass, his latest play recently in repertory at London's National Theatre. The weighty themes are leavened by the hallmark wry humour, sparkling dialogue and deft characterisation.

The title of the play places it in the days following Kristallnacht when Jewish shopfronts were smashed, and the streets covered in broken glass. The main characters presented are Philip Gellburg, his long-suffering wife, the lovely Sylvia, and Dr Hyman, the charismatic family practitioner. Sylvia is well-loved in the neighbourhood for her gentle personality and grace, and is unusual in Hyman's eyes for being remarkably well-informed. Hyman takes a personal interest in her case. Against the advice of his wife and despite his professed ignorance of psychiatry, he embarks on ad hoc therapy, and becomes captivated by his patient who develops an equally strong attachment. Vanity prevents him from referring to a specialist even when he finds himself out of his depth.

His approach is rather unorthodox; "I want you to imagine that we've made love .... and you begin to tell me some secret things. Things that are way down deep in your heart ..... Naively he exhorts her to "send your thoughts down into your hips ... tense those hips ... do it for me .. .!" Following Dr Hyman's suggestions, Philip Gellburg sets about winning his wife back, greeting her with an uncharacteristic kiss on the cheek, holding her hand, promising to buy her a car, even suggesting the couple sit down with the good doctor "and maybe talk about, you know, everything ..... Sylvia scornfully rejects his fumbling overtures. Frustrated and angry, Philip accuses his wife of duplicity, and begins to mistrust the debonair Hyman and his theories.

He cannot believe that Sylvia could be so deeply affected by the pictures in the papers from a place 3,000 miles away - old men with long beards scrubbing the pavements with toothbrushes, the jeering of onlookers, the rounds of arrests. Furthermore, he resents the German Jews because they come to the US and seem to want the best jobs. Philip boasts of being the only Jew who made it in his business, and that through the benevolence of his smug WASP boss, his only son Jerome is the only Jew at Westpoint 